\title{
Factors Influencing the Learning Management System (LMS) Success Among Undergraduate Students in Limkokwing University of Creative Technology, Malaysia
}

\author{
Suha Fouad Salem ${ }^{1 *}$; Sharif Omer Salem ${ }^{2}$ \\ ${ }^{1}$ Faculty of Business management \& Globalization, Limkokwing University of Creative Technology \\ E-mail: ssalemp@gmail.com \\ ${ }^{2}$ Post Graduate Center, Limkokwing University of Creative Technology \\ Email: ssalemg@gmail.com
}

\begin{abstract}
In the last few years, there has been an increase in the number of e-learning systems being added into the educational processes. One of them is the Learning management system (LMS), an educational program that is based on web technology. The programs in this system provide support to instructors to achieve their pedagogical goals, organize course contents that in turn support students' learning process. The aim of this study is to investigate the factors that have brought success to the learning management system. The study examines the relationship between students' outcomes (Perceived Usefulness) and information quality, for online learning through system use and user satisfaction. The respondents chosen for this study are undergraduate students from Limkokwing University in Malaysia. The number of respondents selected as sample of this study is based on the number of students in each faculty. The quantitative data are obtained from a survey using questionnaires. The analysis of the available data indicated that all relationships from independent variables to mediating variables and from mediating variables to dependent variable are significant, the most influential path was information quality $\rightarrow$ user satisfaction $\rightarrow$ perceived usefulness.
\end{abstract}

Keywords: Learning management system, DeLone \& McLean model, Higher education

\section{Introduction}

The learning process requires techniques and tools to present content or knowledge from various resources, followed by the communication and sharing of knowledge matters with others. For this reason, learning has become an important tool to achieve the learning goals. Electronic learning (e-learning) which refers to learning via the internet has become a major phenomenon in recent years. Schools and corporations are investing amounts heavily in terms of time and money in the development of alternative educational methods to replace the traditional types of learning systems (Wang, Wang, \& Shee, 2007). Many academic institutions have invested huge amount of money in the implementation of LMS to 
support online teaching (Naveh, Tubin, \& Pliskin, 2010). In previous studies, Learning Management System is defined as a learning management system with the infrastructure to deliver and manage instructional content, identify and assess individual and organizational learning or training goals, track the progress towards the achievement of these goals, and collect and present data for the supervision of the learning process of an organization as a whole (Szabo, 2002). The success story of LMS lies with different indicators identified in previous research studies. Most of the studies revealed that the two significant factors that contribute to the effectiveness of LMS (Naveh et al., 2010).

Generally, no studies have been implemented to investigate the factors that contribute to the success of the learning management system that has influenced students' learning outcomes in Limkokwing University, Malaysia.

\section{Purpose of the study}

The main purpose of this research study is to investigate the factors that contribute to the success of the learning management system that has influenced the learning outcomes of undergraduate students who are in semester three and above in Limkokwing University of Creative Technology, Malaysia.

\section{Research Questions}

The following specific research questions are formulated to fulfil the aims of this research study:

1- To what extent does information quality will lead to system use and user satisfaction?

2- To what extent does system use will lead to user satisfaction?

3- To what extent does system use and user satisfaction will lead to perceived usefulness?

\section{Literature Review}

\section{Theoretical Background}

This study is based a model by DeLone \& McLean as a theoretical foundation. The ISS model can be used to assess the success of LMS due to solid theoretical foundation and the numerous successful empirical studies.

The DeLone and McLean model is one of the most widely cited IS success models (Sedera \& Gable, 2004; Heo \& Han, 2003), that suggests a combination of independent measures from categories of IS success making it an extensive measurement instrument. It consists of six IS success dimensions namely; (1) system quality, (2) information quality, (3) system use, (4) user satisfaction, (5) individual impact and (6) organizational impact. Since 1992, many research studies by Etezadi-Amoli \& Farhoomand, (1996); Goodhue \& Thompson, (1995); Guimaraes \& Igbaria, (1997); Igbaria \& Tan, (1998); Rai, Lang, \& Welker, (2002); Sedon \& Kiew, (1995) have conducted have empirical investigations of the relationships between the measures of IS success. Recently, Delone \& McLean, (2003) proposed an updated IS success model. There is a need to evaluate its usefulness because of the radical changes in IS practice, especially the changes and growth of Internet-based applications. The updated IS success model of Delone \& McLean, (2003) can be adapted to meet the challenges of measurement of a new e-learning context. 
Consequently, Wang et al., (2007) develop an instrument for the assessment of the success of e-learning systems in an organizational context based on the IS success model of Delone \& McLean, (2003).

\section{Learning Management System (LMS) in Limkokwing University}

The learning management system of Limkokwing University was developed in July 2009. The software is developed, for in-house use, in Limkokwing University. It works as a basic learning management system with the main function in the delivery of content and materials from instructor to students. Other action functions of the learning management system include tracking the performance and financial status of the students. In addition, students can gain benefits from some of the features provided by the system such as use of e-library and to obtain further learning.

\section{Conceptualizations of Research Constructs}

\section{Information Quality}

Information quality contribute significantly to the success of e-learning system. This factor, quality of information refers to the measurement of IS output, mainly the quality of the information produced by the system, which is primarily in the form of reports (Halawi, Mccarthy, \& Aronson, 2008). At the same time

, it also includes the characteristics of the quality of information. They are accuracy, precision, reliability, completeness, conciseness, relevance, understandable, meaningfulness, timely, comparability, and format. Most of the earlier focused on IS success models as a whole studies and examined the relationship between information quality and use (Petter, DeLone, \& McLean, 2008). Rai et al., (2002) found that information quality is significantly related to use, when use is measured in terms of dependence of system. Wu \& Wang, (2006) found that information quality influenced user satisfaction in a significant and positive manner. In addition, information quality is positively associated with system use. According to Lin \& Lu, (2000) the features and accuracy of information can affect users' acceptance of the system.

\section{System Use}

System use is an important measure of the success of a particular system (DeLone \& McLean, 1992; Van der Heijden, 2004). It can be defined as the extent and nature of use of an IS success model (Van der Heijden, 2004). In an e-learning system, students perceive the usage of the system as to whether or not the ELS adds value to their learning experience. Some researches argue that system usage leads to user satisfaction, while others researchers believe that user satisfaction leads to system usage. While Delone \& McLean (1992) believe in effects of usage on satisfaction, Pituch \& Lee, (2006) support path analysis whereby system utilization leads to user satisfaction. The findings show positive relationship between these two factors. According to Torkzadeh \& Dwyer, (1994) the findings of path analysis revealed that the effect of system usage on satisfaction was slightly greater than the effect of satisfaction on system usage (p.345).

\section{User Satisfaction}

User satisfaction is a factor used in various models in many research studies. And satisfaction is defined as" the sum of one's feelings and attitudes toward a variety of factors affecting the situation" (Bailey \& Pearson, 1983). Besides that, user satisfaction can be defined as the extent to which users believe the IS 
meets their needs (Ives, Olson, \& Baroudi, 1983). The research results obtained from studies by Lucas Jr, (1978) and Robey, (1979) provide evidence that heavily used systems are positively related to user satisfaction. However, for an e-learning system, the more the usage of the system does not necessarily lead to user satisfaction due to the emphasis and differences that are characteristics of an online course environment (Freeze, Alshare, Lane, \& Wen, 2010).

\section{Perceived Usefulness}

TAM identifies perceived usefulness as the degrees of improvement in work after the adoption of a system. In another study, perceived usefulness is defined as the degree to which a person believes that using a particular system would enhance his or her job performance (Davis, 1989). The usefulness of elearning is an important factor that affect the effectiveness of e-learning among learners (Lim, Lee, \& Nam, 2007). Previous research studies have shown that individuals are more likely to use a new technology if they perceive that it is easy to use, and there are many evidences to show that perceived ease of use will influence perceived usefulness (Saadé \& Bahli, 2005). In this way, perceived usefulness has been adopted as an important representation of IS success model (Wu \& Wang, 2006).

\section{Proposed Model}

As a start, this research study uses the approach developed by Stapleton, Mcallister, \& Schwieger, (2009) for the examination of the success of E-Learning in Higher Education Environment. The model being examined success in E-learning focused on four factors, namely: information quality, system use, user satisfaction, and perceived usefulness.

This model supposed that information quality have impact on system use and user satisfaction which affect perceived usefulness.

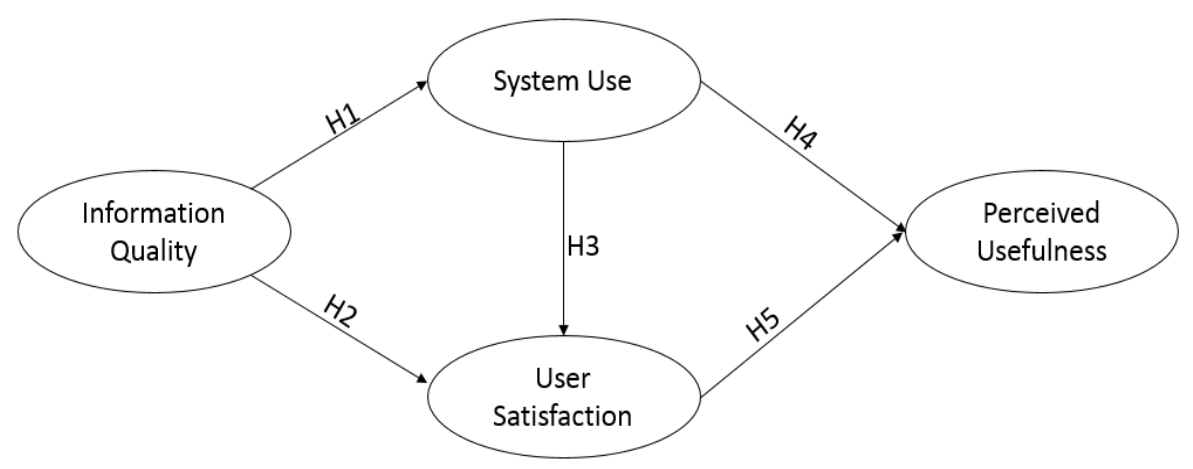

Fig. 1 Proposed research model 


\section{Method}

\section{Measures of the constructs}

A self-report questionnaire was developed for the survey. The respondents were asked to provide demographic information followed by giving Reponses to 16 items on four constructs information quality, system use, user satisfaction, and perceived usefulness in the questionnaire. These items have been used in several previous studies of the e-learning system (Stapleton, Mcallister, \& Schwieger, 2009; Ramayah, Ahmad, \& Lo, 2010; Holsapple \& Lee-Post, 2006; Sun, Tsai, Finger, Chen, \& Yeh, 2008; Alshare, Freeze, Lane, \& Wen, 2011; Davis, 1989). Respondents were asked to indicate the items on a five-point Likert scale ranging from strongly disagree, disagree, Neutral, Agree and strongly agree. All the items in the questionnaire were presented in English language.

\section{Subjects and procedure}

The data used to assess the proposal research model were obtained from the convenience sampling approach. This survey was open to participants who an undergraduate bachelor degree students of semester three or above in Limkokwing University in Malaysia. A total of 370 respondents completed the questionnaires in the survey. The questionnaires were distributed and collected on the same day, specifically during the final hour on the last day of lecture. On the average, students took about 15 minutes to complete the questionnaire.

\section{Scale Validation}

The partial least square (PLS) method was used for the assessment of scales validity and the testing of the hypotheses. This method is a structural equation modeling technique that employs a non-parametric and component-based approach for a predictive research model (Jöreskog \& Sörbom, 1993). The method is preferred over covariance-based analytical techniques such as LISREL, in terms of requirments for sample size and distribution restrictions. In addition, this method is able to model latent variables as either formative or reflective constructs (Chin, Marcolin, \& Newsted, 2003). The SmartPLS software was used to test the hypotheses (Henseler, Ringle, \& Sinkovics, 2009). Unlike LISREL, SmartPLS estimates the parameters of both the measurement model and the structural model. Thus, the relative statistics of the propsed research model were rearranged in terms of the requirements of the measurement model and the structural model. Convergent validity and discriminant validity of scale items were assessed in the measurement model. Meanwhile, the path coefficients and variances explained were assessed in the structural model. Since PLS did not provide any significant test or intervals in the estimation of confidence, a bootstrapping technique with 100 subsamples was used for deriving parameter means, standard errors, and significance for itemloadings, itemweights, and path coefficients.

Convergent and discriminant validity of each first-order construct were assessed in the measurement model. Each first-order construct was modeled as a reflective latent construct accounting for its indicators. Three criteria were used for the assessment of convergent validity (Fornell \& Larcker, 1981). They are: item loading, composite reliability and average variance extracted (AVE). each item loading (l) should be statistically significant and larger than 0.71 . the composite reliability for each latent construct should be larger than 0.70 and it should be interpreted like a Cronbach's coefficient. Finally, the average variance extracted (AVE) of each latent construct should exceed 0.50 . the discriminant validity between

constructs was estimated using the criterion that the square root of every AVE should exceed the correlations among any pair of latent constructs (Chin, 1998; Fornell, C. and Larcker, 1981). As shown in 
Table 1 tabulates the standardized item loadings ranging from .72 to .89 , composite reliability ranged from .85 to .88 , and average variance extracted (AVE) ranged from .60 to .74 . All item loadings exceeded 0.5 . Composite reliabilities of each latent construct were larger than .7, and all values of AVE exceeded .50. In addition, the square root of AVE for each construct (diagonal elements) exceeded its correlations with all other constructs (off-diagonal elements). These results demonstrated that satisfactory reliability, convergent and discriminant validity were achieved.

Table 1 Assessment of convergent validity

\begin{tabular}{|c|c|c|c|c|c|c|c|c|c|}
\hline \multirow[t]{2}{*}{ construct } & \multirow[t]{2}{*}{ items } & \multirow{2}{*}{$\begin{array}{l}\text { Item } \\
\text { loadings }\end{array}$} & \multirow{2}{*}{$\begin{array}{l}\text { Composite } \\
\text { reliability }\end{array}$} & \multirow{2}{*}{$\begin{array}{l}\text { Cronbachs } \\
\text { Alpha }\end{array}$} & \multirow[t]{2}{*}{ AVE } & \multicolumn{4}{|c|}{ Correlations } \\
\hline & & & & & & IQ & PU & SU & US \\
\hline IQ & 4 & $.77-.82$ & .86 & .78 & .60 & .77 & & & \\
\hline PU & 4 & $.72-.87$ & .86 & .76 & .67 & .63 & .81 & & \\
\hline SU & 2 & $.83-.89$ & .88 & .82 & .65 & .40 & .46 & .80 & \\
\hline US & 3 & $.76-.86$ & .85 & .66 & .74 & .65 & .70 & .42 & .81 \\
\hline
\end{tabular}

\section{Assessment of structural model and hypotheses testing}

SMART PLS was used to assess the statistical significance of each hypothesis with consideration that the path coefficient values are standardized betas. The data set comparsis of 380 samples, analyzed with a bootstrapping procedure to evaluate the significance level of the relations between constructs. Figure 1 shows the cofficients of the estimated path of the structural model.

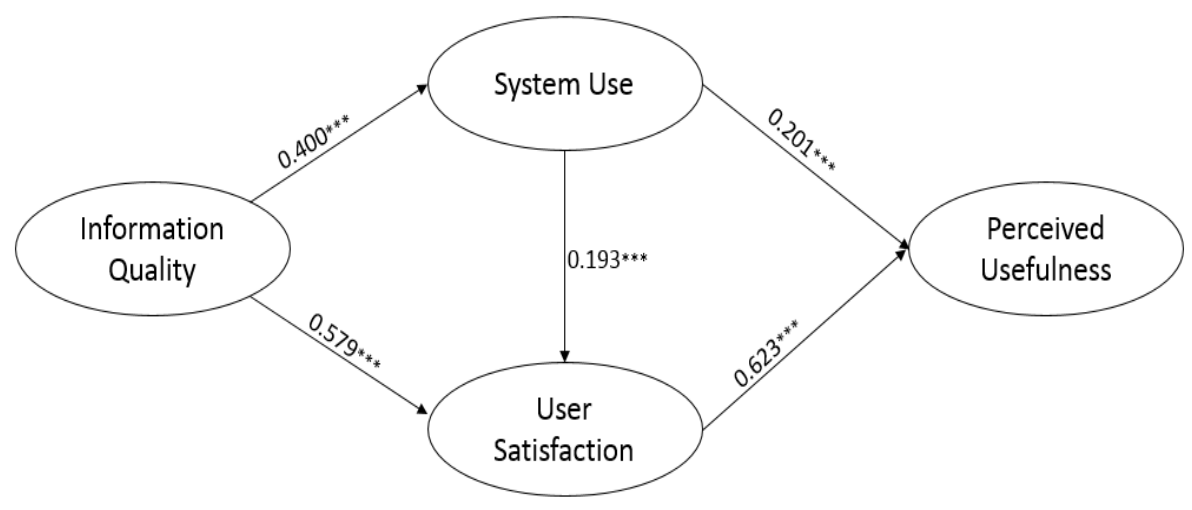

Fig. 2 Results of the proposed research model

Path significance: $* \mathrm{p}<0.05 ; * * \mathrm{p}<0.01 ; * * * \mathrm{p}<0.001$ 
Table 2 is a summary of hypotheses tests, the $\mathrm{T}$ values were used to evaluate the significance of path coefficients. When the $\mathrm{T}$ values were considered, it was found that there were strong positive relations between IQ-SU, IQ-US, SU-US, SU-PU, and US-PU at the p<0.001 level. Therefore, H1, H2, H3, H4 and H5 are accepted. The findings in the analysis of the structural model indicated that the relationship between user satisfaction (US) and perceived usefulness (PU) is the strongest at the $\mathrm{p}<0.001$ level.

Table 2 Summary of hypotheses tests.

\begin{tabular}{lllll}
\hline Relationships & Hi & T-values & $\begin{array}{l}\text { Path } \\
\text { coffecient }\end{array}$ & Decision \\
IQ $\rightarrow$ SU & H1 & 7.263 & 0.400 & Accepted \\
IQ $\rightarrow$ US & H2 & 12.366 & 0.579 & Accepted \\
SU $\rightarrow$ US & H3 & 4.278 & 0.193 & Accepted \\
SU $\rightarrow$ PU & H4 & 4.357 & 0.201 & Accepted \\
US $\rightarrow$ PU & H5 & 15.047 & 0.623 & Accepted
\end{tabular}

\section{Discussion and conclusion}

This study aims to investigate the factors that have successfully influenced the learning management system among undergraduate students in Limkokwing University of Creative Technology, Malaysia. The analysis of the demographic section of the questionnaire revealed that $83.2 \%$ of the respondents are from age group of 18-25 years old. The respondents are from 52 different nationalities which accounts for a highly diverse sample. Most of the respondents were from semesters three, four and five with a distribution of $35.7 \%$ from third semester, $29.8 \%$ from fourth semester and $22.9 \%$ from fifth semester. The findings of the analysis indicated all the relationships from independent variables to mediating variables and from mediating variables to dependent variable are significant.

The results showed that user satisfaction has made the strongest impact on perceived usefulness compared with the other independent variables. It was at a significant value of $p<0.001$.

The variable Information quality has strong influence on user satisfaction. This means when students concerned about the quality of information, they will inevitably become satisfied with the system. Besides that, information quality also impacts system use. This means the quality of information of the learning management system (LMS) is of almost important for the students and it became the main factor that make them use this system as part of their routine. When the students are satisfied with the system they are likely to use this system for their learning due to their belief that the system is beneficial to their studies. Eventually, when the students find they understand better, they show improvements in their academic performance. Therefore, it is clear that the most influential path for LMS begins with of information quality leading to user satisfaction and finally to perceived usefulness.

There are several areas for future research in investigation of the success of LMS. One of them is the investigation on the impact of the characteristics of the instructor who are engaged in the use of LMS. Also, the investigation of the success of LMS from the perspective of instructors is a possible research point. 


\section{References:}

Alshare, K. A., Freeze, R. D., Lane, P. L., \& Wen, H. J. (2011). The Impacts of System and Human Factors on Online Learning Systems Use and. Decision Sciences Journal of Innovative Education, 9(3), 437-461.

Bailey, J. E., \& Pearson, S. W. (1983). Development of a tool for measuring and analyzing computer user satisfaction. Management Science, 29(5), 530-545.

Chin, W. W. (1998). Commentary: Issues and opinion on structural equation modeling. JSTOR.

Chin, W. W., Marcolin, B. L., \& Newsted, P. R. (2003). A partial least squares latent variable modeling approach for measuring interaction effects: Results from a Monte Carlo simulation study and an electronic-mail emotion/adoption study. Information Systems Research, 14(2), 189-217.

Davis, F. D. (1989). Perceived usefulness, perceived ease of use, and user acceptance of information technology. MIS Quarterly, 319-340.

DeLone, W. H., \& McLean, E. R. (1992). Information systems success: The quest for the dependent variable. Information Systems Research, 3(1), 60-95.

Delone, W. H., \& McLean, E. R. (2003). The DeLone and McLean model of information systems success: a ten-year update. Journal of Management Information Systems, 19(4), 9-30.

Etezadi-Amoli, J., \& Farhoomand, A. F. (1996). A structural model of end user computing satisfaction and user performance. Information \& Management, 30(2), 65-73.

Fornell, C., \& Larcker, D. F. (1981). Evaluating structural equation models with unobservable variables and measurement error. Journal of Marketing Research, 39-50.

Freeze, R. D., Alshare, K. A., Lane, P. L., \& Wen, H. J. (2010). IS Success Model in E-Learning Context Based on Students' Perceptions. Journal of Information Systems, 21(2), 173-184.

Goodhue, D. L., \& Thompson, R. L. (1995). Task-Technology Fit and Individual Performance. MIS Quarterly, 19(2), 213. doi:10.2307/249689

Guimaraes, T., \& Igbaria, M. (1997). Client/Server System Success: Exploring the Human Side. Decision Sciences, 28(4), 851-876.

Halawi, L. A., Mccarthy, R. V, \& Aronson, J. E. (2008). An Emprical Investingation of Knowledge Mangement System' Sucess. Computer Information Systems, 48(2), 121.

Henseler, J., Ringle, C. M., \& Sinkovics, R. (2009). The use of partial least squares path modeling in international marketing. Advan in International Marketing, 20(2009), 277-319. doi:10.1108/S14747979(2009)0000020014

Heo, J., \& Han, I. (2003). Performance measure of information systems (IS) in evolving computing environments: An empirical investigation. Information and Management, 40(4), 243-256.

Holsapple, C. W., \& Lee-Post, A. (2006). Defining, Assessing, and Promoting E-Learning Success: An Information Systems Perspective. Decision Sciences Journal of Innovative Education, 4(1), 67-85. doi:10.1111/j.1540-4609.2006.00102.x

Igbaria, M., \& Tan, M. (1998). The consequences of information technology acceptance on subsequent individual performance. Information and Management, 32(3), 113-121. 
Ives, B., Olson, M. H., \& Baroudi, J. J. (1983). The measurement of user information satisfaction. Communications of the ACM, 26(10), 785-793.

Jöreskog, K. G., \& Sörbom, D. (1993). LISREL 8: Structural equation modeling with the SIMPLIS command language. Scientific Software International. Scientific Software International.

Lim, H., Lee, S.-G., \& Nam, K. (2007). Validating E - learning factors affecting training effectiveness. International Journal of Information Management, 27(1), 22-35.

Lin, J. C., \& Lu, H. (2000). Towards an understanding of the behavioural intention to use a web site. International Journal of Information Management, 20(3), 197-208.

Lucas Jr, H. C. (1978). Empirical evidence for a descriptive model of implementation. MIs Quarterly, 2742.

Naveh, G., Tubin, D., \& Pliskin, N. (2010). Student LMS use and satisfaction in academic institutions: The organizational perspective. The Internet and Higher Education, 13(3), 127-133.

Pei-Chen Sun a, Ray J. Tsai b, Glenn Finger c, Yueh-Yang Chen d, D. Y. a, \& Tsai b, G. F. D. Y. a. (2008). What drives a successful e-Learning? An empirical investigation of the critical factors influencing learner satisfaction. Computers \& Education, 50(4), 1183-1202. doi:10.1016/j.compedu.2006.11.007

Petter, S., DeLone, W., \& McLean, E. (2008). Measuring information systems success: models, dimensions, measures, and interrelationships. European Journal of Information Systems, 17(3), 236263. doi:10.1057/ejis.2008.15

Pituch, K. A., \& Lee, Y. (2006). The influence of system characteristics on e-learning use. Computers \& Education, 47(2), 222-244. doi:10.1016/j.compedu.2004.10.007

Rai, A., Lang, S. S., \& Welker, R. B. (2002). Assessing the validity of IS success models: An empirical test and theoretical analysis. Information Systems Research, 13(1), 50-69.

Ramayah, T., Ahmad, N. H., \& Lo, M.-C. (2010). The role of quality factors in intention to continue using an e-learning system in Malaysia. Procedia - Social and Behavioral Sciences, 2(2), 54225426. doi:10.1016/j.sbspro.2010.03.885

Robey, D. (1979). User attitudes and management information system use. Academy of Management Journal, 22(3), 527-538.

Saadé, R., \& Bahli, B. (2005). The impact of cognitive absorption on perceived usefulness and perceived ease of use in on-line learning: an extension of the technology acceptance model. Information \& Management, 42(2), 317-327. doi:10.1016/j.im.2003.12.013

Sedera, D., \& Gable, G. (2004). A factor and structural equation analysis of the enterprise systems success measurement model. In Proceedings of the Tenth Americas Conference on Information Systems, New York, New York,. Retrieved from http://eprints.qut.edu.au/4733/

Sedon, P., \& Kiew, M. (1995). A Partial Test and Development of the DeLone and McLean model of IS success. JI DeGross, SL Huff and MC Munro. In Proceeding of the Fifteenth International Conference on Information Systems (pp. 99-110).

Stapleton, J., Mcallister, C., \& Schwieger, D. (2009). Examination of E-Learning Success in the Higher Education Environment: A Case Study. In Proceedings of the Fourth Midwest United States Association for Information Systems Conference. 
Sun, P.-C., Tsai, R. J., Finger, G., Chen, Y.-Y., \& Yeh, D. (2008). What drives a successful e-Learning? An empirical investigation of the critical factors influencing learner satisfaction. Computers \& Education, 50(4), 1183-1202.

Szabo, M. (2002). Cmi theory and practice: Historical roots of learning managment systems. In World Conference on E-Learning in Corporate, Government, Healthcare, and Higher Education (Vol. 2002, pp. 929-936).

Torkzadeh, G., \& Dwyer, D. J. (1994). A path analytic study of determinants of information system usage. Omega, 22(4), 339-348.

Van der Heijden, H. (2004). Hedonic information systems. MIS Quarterly, 25(4), 695-704.

Wang, Y., Wang, H., \& Shee, D. (2007). Measuring e-learning systems success in an organizational context: Scale development and validation. Computers in Human Behavior, 23(4), 1792-1808. doi:10.1016/j.chb.2005.10.006

Wu, J.-H., \& Wang, Y.-M. (2006). Measuring KMS success: A respecification of the DeLone and McLean's model. Information \& Management, 43(6), 728-739 